DOI https://doi.org/10.36059/978-966-397-207-7/161-179

\title{
PUNISHMENT AND MEASURES OF RESOCIALIZATION (SOCIAL ADAPTATION) IN JUVENILE CRIME PREVENTION POLICY: COMPARATIVE ANALYSIS
}

\section{Yuzikova N. S.}

\section{INTRODUCTION}

The attitude of society towards the criminal behaviour of minors is established at the level of the historical period. Punishment and other measures of a social, rehabilitation corrective nature, were consistent with the level (indicators) of crime. The institute of punishment of minors reflected was stages of development of society and the state.

The problem of crime and the punishment of minors has always attracted the attention of criminologists. Because society connects its present and future with this age group.

It is a constant position that juvenile delinquency remains the most active, defiant and dangerous component of overall crime. The problems of juvenile delinquency prevention have always been particularly acute. Their decision is about security in society. According to research, adult criminals have acquired their first criminal experience, mostly in the juvenile age. Juvenile delinquency is a kind of indicator of the social situation and the level of security in the country.

Increase in juvenile crime, testifies to negative processes in the country, the crisis of punishment, the not effectiveness of preventive measures.

The criminological analysis of juvenile delinquency is:

a) an instrument for isolating criminogenic factors in the juvenile environment and in society;

b) the basis for predicting felonious acts as a whole;

c) the scientific basis for formulating crime prevention policies.

Therefore, the experience of European countries in which juvenile delinquency is minimal is of scientific and practical interest.

The task posed in the title of the article is complex, voluminous and limitless. It is impossible to disclose in the framework of one 
scientific publication. Therefore, attention will be focused on the following areas:

a) aims and effectiveness of punishment;

b) implementation of the goals of correction, re-socialization in different types of punishment;

c) principles of juvenile prevention policy

d) foreign experience in preventing juvenile delinquency.

\section{Objective possibilities of punishment in the prevention of minor delinquency}

Prevention of juvenile delinquency is carried out: firstly, through a criminal law prohibition, which is enshrined in the Criminal Code of Ukraine; secondly, by punishing minor of crime offense.

Among the variety of measures to combat minors delinquency, the most common and severe was and remains punishment. The punishment is aimed at punitive effect, correcting the convicted person and preventing the commission of a new crime by both the convicted person (private prevention) and other persons (general prevention) (part 2 of article 50 of the CC of Ukraine).

An acceptable legal and moral environment in society depends on an understanding of the social purpose and significance of the punishment, and on its proper and adequate application. Therefore, the dominant function of punishment is to increase the moral level of citizens of the state and the formation of motivation for law-abiding behavior within the norms and values that prevail in society.

In the system of crime response measures, psycho-corrective security measures, social rehabilitation and compensation measures can be applied on a parity basis. The person guilty of the crime is obliged to bear criminal responsibility, but the forms of implementation of the latter vary - from mandatory restriction of rights to social and personal rehabilitation and re-socialization.

The question of the value of punishment in the prevention of juvenile crime has been a subject of attention since ancient times. There was no clear definition of the place and role of the criminal penalty in the prevention system. In the era of the New Age, scientists paid attention to humanization in law enforcement and preventive practice. So, Charles Louis Montesquieu, John Locke in their works 
preferred the education of a new generation and the prevention of offenses over punishing a child for a crime ${ }^{1}$.

There is no unambiguous assessment of the role of criminal punishment (stringency or humanity) in preventing and combating crime. Studies of foreign scientists (Hellmani U., Baltzer Ulrikh, John F. Stinneford) indicate the need for humanization of the criminal policy. This is complies with international standards. In addition, the increase in the "prison population" and the acquisition of criminal experience by the persons to whom the punishment is applied contributes to the deterioration of the criminal situation and the safety of society ${ }^{2,3,4}$.

Kara, as a form of influence on a minor, fulfills a warning purpose, and does not bring up a person. Punitive and educative impact have a different legal nature. The educational impact is not covered by the objective content of the punishment. It combines with punishment in the process of its implementation. In the absence of educational impact, the purpose of punishment cannot be achieved. Then punishment makes no sense.

The effectiveness of educational impact is ensured with targeted individual punishment. This can be achieved with a differentiated approach to minors. For instance, Margaret Warren classified minors who are imprisoned according, to their level of maturity ${ }^{5}$. During the interview, the level of integration of the minor is determined and a conclusion is made about his social maturity. This became the basis to pick out the following types of personality of a minor:

\footnotetext{
${ }^{1}$ Монтескье Ш.-Л. О духе законов / Ш.-Л. Монтескье. - М. : Наука, 1955.

2 Хелльмани У. Значение превентивного заключения для практики уголовных наказаний в Германии // Союз криминалистов и криминологов. 2013. - № 1. - С. 92-95.

3 Бальтцер Ульріх. Інші заходи кримінально-правового характеру у національному праві Німеччини: від осудного кримінального права до превентивного кримінального права. України власний шлях. Есе німецьких авторів. BWV. Berliner Wissenschafts-Verlag, 2013. - C. 61-65.

${ }^{4}$ John F. Stinneford Incapacitation through Maiming: Chemical Castration, the Eighth Amendment, and the Denial of Human Dignity. University of St. Thomas Law Journal. Volume 3 Issue 3 Spring 2006. P. 559-599

${ }^{5}$ Шнайдер Г. Й. Криминология / Г. Й. Шнайдер ; пер. с нем. ; под общ. ред. и с предисл. Л. О. Иванова. - М. : Прогресс - Универс, 1994. - С. 310-312.
} 
a) an immature conformist who identifies with those who currently have power;

b) a subcultural conformist who agrees with everyone from his group (especially a group of peers);

c) a manipulator artist who undermines the authority of authority and appropriates it to himself.

Such typology is conditional, but can be adapted to the Ukrainian penitentiary system. This can be successfully used for corrective and educative purposes.

Criminologist Joseph f. Shelley analyzes the problem of punishment through public opinion ${ }^{6}$. Public opinion is based on the ancient principle of matching punishment with the heft of the crime. At first glance, the main element is revenge - retribution for a crime and damage.

Professor I.N. Ragimov reveals the nature of the causes of crime, the content, forms and types of punishment. Based on this analysis, it reveals the limits of justice in sentencing and the role of the state in ensuring the rule of law in its implementation ${ }^{7}$. The scientist's analysis of the problem of punishment through history, theology, philosophy, psychology, politics, sociology, mathematics and genetics became the basis for the conclusion about the absence of a "crisis of punishment", and the presence of a "crisis of society" in the fight against crime.

In the process of forming a juvenile preventive policy, a dilemma arises - which devices should be preferred: means of social prevention, correction of behavior, or penalty? It is important to take into account the psychological, physiological, moral and gender, age characteristics of the minor. The criminal law substantiates the consolidation of the specifics of criminal liability and punishment of minors.

The solution to the problem of preventing juvenile delinquency should be concentrated in the following district. The first is to direct

${ }^{6}$ Криминология / под ред. Дж. Ф. Шелли ; пер. с англ. - СПб. : Питер, 2003. - С. 156.

${ }^{7}$ Рагимов И. М. Преступность и наказание / И. М. Рагимов. - М. : ОЛМА Медиа Групп, 2012. - С. 85. 
efforts towards ensuring the optimal functioning of the system for protecting the rights of children in Ukraine.

The second is focusing on protecting and creating conditions for the socialization of the child, linking it with the realization of the social functions of the family, school, and society.

The third is to minimize the influence of environmental factors that determine the criminal behavior of minors.

Fourth - to strengthen work with juvenile offenders of the "risk group".

Fifth, to prevent juvenile crime recurrence by using the resocialization and adaptation of a minor to life in society. Resocialization - the conscious renewal of a convicted person in the social status of a normal member of society; a return to independent, generally accepted life in society. The main means of resocialization are: the procedure for the execution and serving of sentences; socially useful work; social educational work; education; public influence (Article 6 of the Criminal Executive Code of Ukraine). Resocialization is applied taking into account the type of punishment; the personality of the convicted person is taken into account; public danger of crime; motives for committing a crime.

The lack of effectiveness of punishment and the significant use of imprisonment for minors - does not correct the minor, and does not reduce violence in society. Therefore, it does not contribute to the restoration of law and order and the formation of harmony in the state.

Today, to solve the problems of preventing juvenile crime, it is necessary to replace the punitive approach with a new one - a humanistic one. It is necessary to apply scientifically based measures that correspond to the nature and level of criminalization of public relations. These measures should dominate juvenile preventive policies.

\section{The unity of correctional and social adaptation elements in the process of implementing certain types of punishments}

Statistics show that in Ukraine the number of crimes committed by minors is gradually decreasing. This indicates effective measures of influence and social adaptation in the process of execution of the punishment. Thus, the dynamics of juvenile delinquency is directly related to the effectiveness of punishment and social adaptation. 


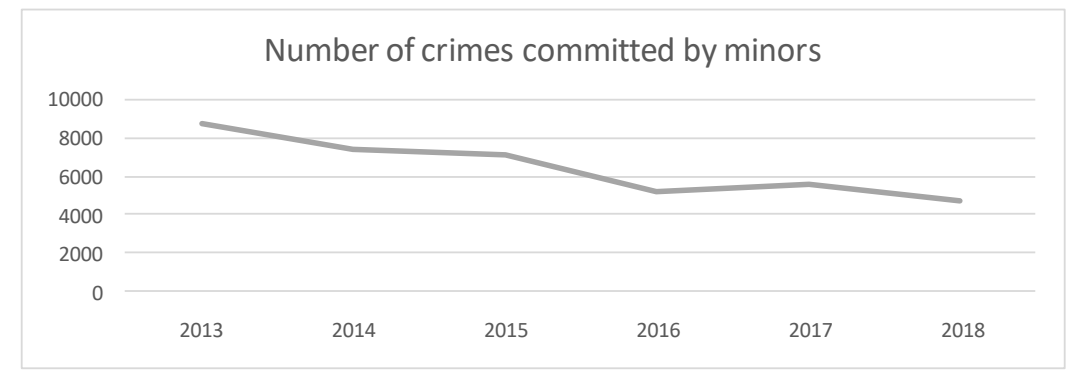

Table

Number of crimes committed by minors ${ }^{8}$

\begin{tabular}{|c|c|c|c|c|c|c|}
\hline years & 2013 & 2014 & 2015 & 2016 & 2017 & 2018 \\
\hline $\begin{array}{c}\text { number of } \\
\text { crimes }\end{array}$ & 8781 & 7467 & 7171 & 5230 & 5608 & 4750 \\
\hline
\end{tabular}

Correction and social adaptation are most fully manifested in the process of implementing certain types of punishments. When executing the punishment, independent tasks are solved: the implementation of punitive influence (restrictions and deprivations), correction, prevention and social adaptation

Providing legal protection for the rights of the child who committed the crime is reflected in the legislative consolidation of the specifics of criminal liability and punishment of minors in the Criminal Code of Ukraine. The content of the features of criminal liability and punishment consists in their individualization. Individualization is based on the maximum consideration of the psychological, moral and age characteristics of the child. Highlighting the peculiarities of punishment of minors is consistent with the principles of the rule of law of justice, humanism, minimal criminal repression.

The Criminal Code of Ukraine contains an exhaustive list of types of punishments that can be applied to minors. The main punishments is: 1) a fine; 2) community service; 3) correctional work; 4) arrest;

8 Статистична інформація про стан злочинності за 2013-2018 роки . https://www.gp.gov.ua/ua/statinfo 
5) deprivation of liberty for a fixed term (part 1 of article 98 of the Criminal Code of Ukraine).

Additional punishments include: 1) a fine; 2) deprivation of the right to occupy certain positions and engage in certain activities (part 2 of article 98 of the Criminal Code of Ukraine). Judicial statistics show a small percentage apply, to minors who have committed a crime, additional punishments.

A fine may be imposed on a minor as a basic or additional punishment. A fine is prevalent type of punishment (the proportion is $24 \%$ of all types of punishment). The basis for the purpose of the penalty is the presence in the minor's independent income, own funds or property.

Community service is assigned to minors aged 16 to 18 for a period of thirty to one hundred and twenty hours (the proportion is $14 \%$ of all types of punishment). A minor performs community service in his free time from studies or main work (no more than two hours a day). When applying community service to minors, there are regulatory restrictions. The Code of laws on labor in Ukraine prohibits certain types of work for persons under 18 years of age (Article 190); a ban on involving minors in night work and weekend work (Article 192).

Correctional work is assigned to minors aged 16 to 18 at the place of work for a period of two months to one year. This type of punishment is rarely assigned to minors (the proportion is $1.8 \%$ of all types of punishment). The seldom application of correctional labor for a minor is due to social and economic conditions in Ukraine. It is difficult for minors to find work without work experience, life experience, education and specialty. Control over the execution of this type of punishment rests with the probation authority. In conditions of high unemployment, the state should take care of creating conditions for the implementation of punishment.

The arrest consists of keeping a minor who has reached sixteen years of age, in isolation in special institutions. The period of arrest is from fifteen to forty-five days. The arrests apply to minors who have reached the age of sixteen. The punishment is isolation in special institutions for minors. The period of arrest is from fifteen to fortyfive days. Stable juvenile arrest rate (less than $2 \%$ ). 
Imprisonment is imposed on minors who have committed a crime for a period of six months to ten years (the proportion is $48 \%$ of all types of punishment). Juveniles sentenced to deprivation of liberty are serving their sentences in the special educative institutions. Deprivation of liberty cannot be assigned to a minor who has committed a minor offense for the first time.

The effectiveness of punishment, its preventive nature are directly related to the public danger of the crime. An important component of state preventive policy is the humane component. The release of the minor from punishment is a factor of trust in him and the hope that in the future he will not commit crimes. An alternative to punishment must be sought, not alternative punishment.

The recommendations of the United Nations Standard Minimum Rules for the Administration of Juvenile Justice ("Beijing Rules") are aimed at limiting application of the deprivation of liberty to minors (paragraph 19 of the Beijing Rules). In accordance with international standards, Ukraine adopted the «Strategy for the reform of the judicial system, legal proceedings and related legal institutions for 2015-2020».

The «Strategy for the reform of the judicial system, legal proceedings and related legal institutions for 2015-2020» aims to increase the effectiveness of the prevention of recidivism; to rehabilitation of convicts and improvement of the penal system; reduction of punishment related to imprisonment ${ }^{9}$.

A set of measures aimed at improving the effectiveness of crime prevention and rehabilitation of convicts includes the following:

- Development and practical application of modern approaches to the management of prisons, modernization of prison infrastructure;

- Improvement of ethical and disciplinary rules and internal control mechanisms in prisons;

- Improving the system for serving sentences by minors, ensuring their right to continue education and vocational tutoring;

9 Про Стратегію реформування судоустрою, судочинства та суміжних правових інститутів на 2015-2020 роки [Електронний ресурс] : Указ Президента України від 20.05.2015 p. - Режим доступу : http://zakon4.rada.gov.ua/laws/show/276/2015 
- The introduction of an individual approach to serving sentences, improving security measures in prisons;

- Combating and preventing against mistreatment of convicts in prisons through external supervision and independent monitoring;

- Improving the legal framework for punishment and probation;

- Reduction in the number of punishment related to deprivation of liberty;

- Education personnel, giving technical base for the functioning of the probation service ( p. 5.11 Strategy for the reform of the judicial system, legal proceedings and related legal institutions for 2015-2020).

In Ukraine, a humane system of punishment has been created and is operating, which applies to minors who have committed a crime. The punishment system is in line with international standards for the protection of the rights of the child and juvenile justice.

\section{The principles of juvenile preventive policy}

The state crime prevention policy consists of three successive stages. The first is conceptual ideas (provisions) that reflect the attitude of the state and society towards the criminal behavior of minors. At this stage, there is a process of forming a policy for the prevention of juvenile crime. It should be normatively fixed.

The second - characterizes the activities of the state and civil society institutions aimed of the implementation of conceptual ideas (provisions) that are formed at the first stage.

The third - reflects the expected results from the practical implementation of conceptual ideas (provisions).

The last stage is an indicator of the effectiveness of conceptual ideas (provisions) and forms, methods and means of their implementation. This stage is an indicator of the effectiveness of juvenile crime prevention policies. It is accompanied by highly professional systematic analytical and informational work of crime prevention entities. Analysts determine the level of public confidence in the activities of prevention entities and determine the level of effectiveness of law enforcement practice.

The El Salvador Declaration, adopted at the XII UN Congress on Crime Prevention and Criminal Justice, noted that «states should 
allocate sufficient human and financial resources to develop and implement effective anti-crime policies, programs and training» (Twelfth United Nations Congress on Crime Prevention and Criminal Justice (Salvador, Brazil April 12-19, 2010 year) ${ }^{10}$.

The object of a preventive policy are crimes committed by minors; risk factors (economic, psychological, cultural, pedagogical, medical, legal). Objects form a preventive policy, and politics, in turn, affects objects. Changes in the objects of a preventive policy determine the effectiveness of this policy. The objects of preventive policy are also: acceptable conditions for the functioning of socialization institutions; activities of socialization agents that form the motivation for lawabiding behavior of a minor.

This approach makes it possible to strengthen social control, identify and take into account the patterns of criminal manifestations and risk factors. These factors form the basis of state preventive policy and determine the necessary vector of influence on its objects.

F. Liszt believed that «criminal policy consists in a systematic presentation of the principles by which the fight against crime is carried out by applying punishment. The principles should be based on the scientific study of crime, its causes and the penalties applied $\gg{ }^{11}$.

In Ukrainian society, the solution to the problem of crime prevention should be based on principles that are reflected preventive policies which minors. This policy is based on legal norms that are aimed at crime prevention. The main principles include the following.

The principle of identifying the age group of minors as a special category of the population, requiring increased protection of rights from early childhood to adulthood.

The principle of the adequacy of means of protecting the rights of the child, which correspond to modern conditions of social, economic, ideological, cultural and international development of society.

${ }^{10}$ Twelfth United Nations Congress on Crime Prevention and Criminal Justice, Salvador, Brazil, 12-19 April 2010 A/CONF.213/18

11 Франц фон Лист. Задачи уголовной политики. Преступление как социальнопатологическое явление / Франц фон Лист. - М. : Инфра-М., 2004. - С. 34 
The principle of adequacy will be able to protect against excessive or insufficient use of means and methods of protecting the rights of the child. This is the creation of centers, organizations; adoption of normative acts; implementation of targeted programs. The wrong approach to juvenile prevention does not protect the rights of the child in society.

The principle of compliance of juvenile preventive policies with the age characteristics of the child. When developing a system of measures to prevent juvenile delinquency, it is important to take into account gender and age-related characteristics at different stages of child socialization.

The principle of systematic and multifaceted activities that are aimed at implementing the social functions of the family, school, society and preventing the criminal behavior of minors. This principle includes a coordination system for preventive activities and a single information space for all crime prevention entities. Prevention measures should be considered as a permanent element of the organization of state and public activities. This does not exclude the holding of individual events that will be temporary or one-time. They should be part of the overall system of programmatic measures. This principle determines the development of preventive programs. Even small-scale preventive measures are of prophylactic importance if they are carried out systematically and are widespread.

The principle of the advantage of measures to prevent criminal behavior over punishment (means of criminal repression). An additional function of punishment is associated with a rational system of different forms of implementing the crime prevention strategy (restorative justice, reconciliation, and others). This system is developing within the framework of public and socially institutions of the family, school, enterprises and society. A restorative approach to juvenile justice should be dominant.

The principle of interdependence of state policy to protect the rights and interests of the child from the volume of criminological knowledge about the violation of the rights and freedoms of minors and the crime of minors. The state policy in the field of juvenile justice is enshrined in national legislation and the practice of its application. The practice destination of punishment by courts should 
be based on knowledge about the structure, level, dynamics of juvenile delinquency and victimological indicators among minors.

The principle of specialization in the criminal justice system. It consists in preparing subjects of the criminal justice system to work with children of different gender and age groups.

The principle of a regional approach to the formation of preventive measures in the general juvenile delinquency prevention system. It includes:

a) an objective assessment of the regional criminogenic and victimogenic situation among minors;

b) the maximum use of the region's capabilities (material, technical, personnel, information, organizational and managerial resources);

c) coordination of local, targeted (one-time, permanent) programs with state programs and concepts of crime prevention.

The Ukrainian Concord Center presented a roadmap "Building a safe community and preventing crime among children and youth". The roadmap includes effective crime prevention measures. These measures include:

a) training programs for resolving conflict situations among children, youth and grown-up;

b) programs for parents;

c) social programs;

d) improvement of the regulatory framework.

The Ukrainian Concord Center pays special attention to the volume of investments that state institutions invest in preventive activities. For the implementation of program measures, it is important that local authorities cooperate with law enforcement agencies, educators and social services. According to the World Health Organization (WHO), every euro invested in a prevention program saves the state 39 euro $^{12}$.

The result of the state policy of preventing juvenile delinquency depends on the level of trust and respect in society for entities that carry out preventive activities. The role and authority of judicial, law enforcement authorities and management is the basis of the

12 Дорожня карта побудови безпечної громади: попередження правопорушень серед дітей та молоді. - К. : Український Центр Порозуміння, 2010. - С. 3. 
effectiveness of preventive activities. Trust and respect for the authorities positively affect the security and development of Ukraine.

In different regions of Ukraine (Vinnitsa, Dnepropetrovsk, Kharkov, Odessa, Kiev, Lvov and others) the project «School Police Officer» was introduced.

The main objective of the project «School Police Officer» is to create a safe environment in secondary schools. This measure is implemented through the implementation of effective crime prevention among students, the use of restorative practices to prevent conflicts, offenses and other negative phenomena

Ukrainian experts, together with their Canadian counterparts, developed guidelines for the School and Police program for educational and preventive classes with students in grades 1-11. This program was approved by the Ministry of Education and Science of Ukraine for use in secondary schools.

To participate in the program «School Police Officer» patrol officers were selected, who underwent training and began to implement the project. Classes are structured as follows: after a short theoretical part, students test the theory in practice. For primary school students (grades 1-4), classes are held in the form of a game. The "School police officer" uses special play sets and dolls. With schoolchildren of middle and senior grades (grades 5-11), various practical situations are worked out in groups. Up to thirty children take part in the lesson. Each pupil participates in a game situation or discussion. This contributes to better absorption of the material.

A separate area of work of «school police officers» is to establish interaction with parents. Predominantly, parents are positive about the conversations of school officers. However, some parents do not understand their status. Parents are fully responsible for the health and well-being of their child. Upbringing methods correspond to modern youth.

\section{Foreign experience in preventing juvenile delinquency}

For Ukraine, a positive example of the effective prevention of juvenile delinquency is programs and measures that are widely used in foreign countries. The goal of many foreign programs is to provide assistance, advice, educational work to eliminate the factors to determine the criminal behavior of minors. 
The Irish Association NIACRO employs early and long-term intervention programs (Garda Juvenile Diversion Programs) ${ }^{13}$.

These programs are aimed at supporting children and parents. Program measures are aimed at developing vital skills in minors; helping parents raise their children; correcting of deviant behavior of minors. The Advice Center of the NIACRO Association works with prisoners, their families and children ${ }^{14}$.

There is no juvenile justice system in Denmark. For juvenile offenders, measures are more often applied that are not related to isolation from society. Of scientific and practical interest is the collaboration between schools, social services and the police within the framework of SSP (schools, social service and police). SSP aims to reduce youth crime ${ }^{15}$. The SSP collaboration is organized on 3 levels:

- The political-strategic level;

- The coordinating level;

- The implementing level.

These levels ensure the implementation of strategies and programs aimed at reducing juvenile delinquency.

At the political-strategic level, annual strategies and action plans are formed. They have an intersectional character. Collaboration is carried out among representatives of the highest ranks of the police, mayors of municipalities and strategic partners at the regional and local levels.

At the coordination level, the activities of coordinators are carried out, which is aimed at implementing strategies and plans. This is a collaboration of local councils and local police. Municipal authorities are responsible for implementing common strategies and action plans.

At the implementation level, targeted and functional activities of local specialists from schools, the police, and social workers are

${ }^{13}$ Children and the criminal justice system in Ireland [Электронный pecypc]. Режим доступа: http://www.citformation.ie/en

14 Веб-сайт NIACRO. Evaluation of the Early Intervention Program. [Електронний ресурс]. Режим доступу: http://www.niacro.co.uk

15 The Danish SSP system: Local collaboration between schools, social service and police [Електронний ресурс]. Режим доступу: https://ec.europa.eu/homeaffairs/node/7488_en 
carried out. These specialists regularly carry out practical coordination of preventive actions at the local level.

An important place in the prevention of juvenile delinquency is confidence in the subjects of prevention.

In Poland, the «Rodzina Policyjna» Association operates to create an atmosphere of trust and respect for traditions in the work of the police. The Association is a voluntary, self-governing and permanent structure that aims to build public trust in the work of the police $(\S 1$ of the Statute of «Rodzina Policyjna») ${ }^{16}$.

The activities of the association are based on the principles of:

- protect of the image of the police in the media and society;

- education and popularization of national traditions of the patriotic attitude of police in the modern world;

- providing moral and material support to police officers who are members of the Association, their family members who find themselves in a difficult life situation.

To implement these principles rally and other events are held annually for participants of the Association. A lot of attention is paid to children, especially with disabilities (special seminars, holidays with gifts). The activities of the Association in accordance with $\S 5$ of the charter have the following aims:

- dissemination of knowledge about the police in society;

- the development of ethics and professionalism of the police;

- cooperation with authorities, institutions and organizations that are interested in the activities of the Association;

- fundraising for the activities of the Association;

- care for close relatives of deceased police officers;

- the creation of summer resorts, nursing homes, dormitories, orphanages and more;

- providing free legal advice to members of the Association;

- organization of the cultural and social life of police officers and their families.

16 Program Zapobiegania Niedostosowaniu Społecznemu i Przestępczosci wśrod Dzieci i Młodziezy. Ministerstwo spraw wewnetrznych i administracji Warszawa, 2003. 
The activities of the Police Athletic League (PAL) are aimed at building trust in the police, working with the local population and protecting children from harmful (illegal) drugs ${ }^{17}$.

The program has been widely adopted in many American and Canadian police departments. Police officers train teenagers in various sports (basketball, football, American football, etc.). Police help to make with homework. Each policeman who participates in the program has additional responsibilities (along with official policeman responsibilities). The aim of the program is to help socialize the child. Children are socialized through the use of education, recreation, national ideas, and art.

The program includes:

1) benefits (day care);

2) educational information centers;

3) computer literacy;

4) training in the process of outdoor activities. The program inspires young people to socially significant life in society.

Wraparound Milwaukee program (USA) is implemented by the Bureau of Milwaukee Child Welfare (Milwaukee Bureau of WellBeing) ${ }^{18}$.

The assistance program consists in individual care for minors who have problems of an emotional, mental and behavioral nature; if need medical attention. Help is provided to children and their families. Participation in the program helps to build relationships with peers; increase the role and family cohesion; minimize the presence of the child outside the home. Participation in the program is for juvenile offenders by court order when the coordinators determine the need for the child to participate in the Milwaukee program.

\section{CONCLUSIONS}

The implementation of the state policy in the field of preventing juvenile delinquency should be based on the principles of humanism, openness, priority measures for social education and correction over

17 Сайт Police Athletic League [Електронний ресурс]. - Режим доступу : http://www.cookcountycourt.org

18 Wraparound Milwaukee [Електронний ресурс]. - Режим доступу : http://wraparoundmke.com 
punishment. The system of preventive policy and punishment of minors who have committed a crime complies with the recommendations of the European Union, UN and UNICEF.

The juvenile crime prevention policy must be implemented taking into account the elements:

1) the priority of educational, upbringing, social measures over punitive measures with forced isolation from society;

2) the widespread introduction of probation rules in the field of juvenile justice (control, guidance, advice, help);

3) mobilization of the resources of the family, educational institutions, society, volunteers in the field of preventing juvenile delinquency;

4) popularization in the media of the positive role of youth in society, minimizing the display of materials related to violence, with drug, to pornography, indignity.

Today's reality indicates the presence of constructive and destructive potential in the younger generation. There can not be totally positive or negative youth. The key point is the degree of deformation of the environment of minors, minimizing the consequences of the negative impact of destructive factors on the behavior of the child and the formation of acceptable conditions for his socialization. All this should be taken into account when punishing minors and applying preventive measures to them.

Foreign programs are aimed at correcting behavior; a mentoring; social support activities; public involvement.

\section{SUMMARY}

The study examined the aims of punishment. Achieving the aims of punishment affects the nature and dynamics of juvenile crime, serves as an effective way of general and special prevention. The criminological analysis of the legal nature of punishment, its aims, types and effectiveness has become the basis for determining the role of criminal punishment (rigor or humanity) in the prevention of crime. The effectiveness of certain types of punishments is reflected in modern crime prevention strategies.

The principles of juvenile preventive policy are laid out, which is the basis for the formation of a safe environment and the development of society. The study of juvenile preventive policy focuses on: training 
qualified personnel; proper funding; involvement of authorities, public organizations and volunteers in preventive activities.

Foreign programs and preventive practices that are effectively used in Denmark, Ireland, Poland, Norway, Canada, and the USA were investigated. Programs are aimed at building trust at the police; involving society in preventive activities; help to children and families.

The study is aimed at studying the effectiveness of punishment and preventive measures (of social and corrective). The possibilities of implementing foreign experience in preventing juvenile delinquency in national practice are being studied.

\section{REFERENCES}

1. Монтескье Ш.-Л. О духе законов / Ш.-Л. Монтескье. - М. : Наука, 1955. - 306 с.

2. Хелльмани У. Значение превентивного заключения для практики уголовных наказаний в Германии // Союз криминалистов и криминологов. - 2013. - № 1. - С. 92-95.

3. Бальтцер Ульріх. Інші заходи кримінально-правового характеру у національному праві Німеччини: від осудного кримінального права до превентивного кримінального права. України власний шлях. Есе німецьких авторів. BWV. Berliner Wissenschafts-Verlag, 2013. - C. 61-65.

4. John F. Stinneford Incapacitation through Maiming: Chemical Castration, the Eighth Amendment, and the Denial of Human Dignity. University of St. Thomas Law Journal. Volume 3 Issue 3 Spring 2006. Р. 559-599.

5. Шнайдер Г. Й. Криминология / Г. Й. Шнайдер ; пер. с нем. ; под общ. ред. и с предисл. Л. О. Иванова. - М. : Прогресс Универс, 1994. - 504 с.

6. Криминология / под ред. Дж. Ф. Шелли ; пер. с англ. СПб. : Питер, 2003. - 864 с.

7. Рагимов И. М. Преступность и наказание И. М. Рагимов. - М. : ОЛМА Медиа Групп, 2012. - 304 с.

8. Статистична інформація про стан злочинності за 20132018 роки . https://www.gp.gov.ua/ua/statinfo

9. Про Стратегію реформування судоустрою, судочинства та суміжних правових інститутів на 2015-2020 роки [Електронний 
ресурс] : Указ Президента України від 20.05.2015 р.. - Режим доступу : http://zakon4.rada.gov.ua/laws/show/276/2015

10. Twelfth United Nations Congress on Crime Prevention and Criminal Justice Salvador, Brazil, 12-19 April 2010 A/CONF.213/18

11.Франц фон Лист. Задачи уголовной политики. Преступление как социально-патологическое явление / Франц фон Лист. - М. : Инфра-М., 2004. - 110 с.

12.Дорожня карта побудови безпечної громади: попередження правопорушень серед дітей та молоді. - К. : Український Центр Порозуміння, 2010. - 25 с.

13. Children and the criminal justice system in Ireland [Электронный pecypc ]. Режим доступа: http://www.citformation.ie/en

14.Веб-сайт NIACRO. Evaluation of the Early Intervention Program. [Електронний ресурс]. Режим доступу: http://www.niacro.co.uk

15.The Danish SSP system: Local collaboration between schools, social service and police [Електронний ресурс]. Режим доступу: https://ec.europa.eu/home-affairs/node/7488_en

16.Program Zapobiegania Niedostosowaniu Społecznemu i Przestępczosci wśrod Dzieci i Młodziezy. Ministerstwo spraw wewnetrznych i administracji Warszawa, 2003. - 100p.

17.Сайт Police Athletic League [Електронний ресурс]. - Режим доступу : http://www.cookcountycourt.org

18.Wraparound Milwaukee [Електронний ресурс]. - Режим доступу : http://wraparoundmke.com

\section{Information about the author: Yuzikova N. S.,}

Professor at the Department of Administrative and Criminal Law, Oles Honchar Dnipro National University 72, Gagarin Ave., Dnipro, 49000, Ukraine 